Article

\title{
Environmental Problem Shifting Analysis of Pollution Control Units in a Coal-Fired Powerplant Based on Multiple Regression and LCA Methodology
}

\author{
Harnpon Phungrassami and Phairat Usubharatana *
}

check for

updates

Citation: Phungrassami, H.; Usubharatana, P. Environmental

Problem Shifting Analysis of

Pollution Control Units in a

Coal-Fired Powerplant Based on Multiple Regression and LCA

Methodology. Sustainability 2021, 13,

5142. https://doi.org/10.3390/

su13095142

Academic Editor: Adam Smoliński

Received: 23 March 2021

Accepted: 27 April 2021

Published: 4 May 2021

Publisher's Note: MDPI stays neutral with regard to jurisdictional claims in published maps and institutional affiliations.

Copyright: (c) 2021 by the authors. Licensee MDPI, Basel, Switzerland. This article is an open access article distributed under the terms and conditions of the Creative Commons Attribution (CC BY) license (https:// creativecommons.org/licenses/by/ $4.0 /)$.
Excellence Center of Eco-Energy, Department of Chemical Engineering, Thammasat School of Engineering, Thammasat University, Khlong Nueng, Khlong Luang, Pathumthani 12120, Thailand; pharnpon@engr.tu.ac.th * Correspondence: uphairat@engr.tu.ac.th

\begin{abstract}
Coal-fired power generation leads to serious environmental pollution, such as air and water pollution; thus, pollution control or treatment is necessary. However, end-of-pipe treatments are still indispensable approaches to reducing environmental stress, and focusing on each in turn leads to pollutant-by-pollutant features. The present study applies the LCA method to reveal the total direct and indirect environmental impacts from increasing significant pollution control units for a coal-fired power plant. From the results, it was found that increasing the performance of CCS and FGD units may result in higher overall environmental impacts due to their energy costs. Greater energy requirements result in greater global warming potential, human toxicity, and terrestrial acidification effects. LNB \& OFA, SCR, and ESP units did not cause any other significant environmental impacts, while activated carbon used in the ACI unit is an additional source of indirect terrestrial acidification. Water depletion effects must be considered when increasing the use of CCS units. Policy makers can use the data from the present study to establish sustainable directions to resolve environmental problems at the macro-economic scale.
\end{abstract}

Keywords: coal-fired powerplant; environmental problem shifting; LCA; pollution control unit

\section{Introduction}

Electricity is a crucial factor for almost all human activities and has a significant role in economic development. The Enerdata Global Energy Statistical Yearbook 2017 shows that in 2016, global electricity consumption had risen after halting in 2015, although this increase was below the long-term growth trend. Non-OECD Asia (China, India, Indonesia, Thailand, etc.), as a region, is the second ranked region contributing to the increasing world electricity consumption. Among these, China contributes over half of that increase. [1]. The framework for climate and energy in 2030 has left many countries setting important goals to address climate change issues. Those involve reducing greenhouse gas emissions and other environmental impacts. Reducing the environmental impact of electricity production is essential due to its importance for primary energy demand.

Coal plays a vital role in electricity generation worldwide. Coal-fired power plants currently fuel $37 \%$ of the global electricity. Since 2000, the world has doubled its coal-fired power capacity to around 2045 gigawatts (GW) after an explosive growth in China and India. A further $200 \mathrm{GW}$ is being built and $300 \mathrm{GW}$ is planned [2]. Coal will still generate $22 \%$ of the world's electricity in 2040, retaining coal's position as the single largest source of electricity worldwide. The promise of cheap electricity to fuel economic growth has driven this expansion. Despite several decades of knowledge about cold-fired powerplant contribution to environmental damage, our economies still rely on it. Focusing on the environmental and health-related externalities $[3,4]$ of coal combustion will likely not be sufficient to phase out coal.

Coal-fired power generation leads to serious environmental pollution, such as air, water, and noise pollution [5-9]. The emissions from the burned coal contain pollutants, 
such as sulfur dioxide $\left(\mathrm{SO}_{2}\right)$, sulfur trioxide $\left(\mathrm{SO}_{3}\right)$, nitrogen oxides $\left(\mathrm{NO}_{\mathrm{x}}\right)$, nitrous oxide $\left(\mathrm{N}_{2} \mathrm{O}\right)$, carbon dioxide $\left(\mathrm{CO}_{2}\right)$, particulate matter $(\mathrm{PM})$, mercury $(\mathrm{Hg})$, trace metals, and radioactive nucleoids [10]. The ratio of the above emissions depends on the type of coal. The emission of gases such as $\mathrm{SO}_{\mathrm{x}}$ and $\mathrm{NO}_{\mathrm{x}}$ react with atmospheric air to create acidic compounds, which precipitate as acid rain. Particulate matter may cause asthma and chronic bronchitis [11]. Coal-fired powerplants are also considered as one of the largest anthropogenic sources of mercury emission into the atmosphere [12]. Due to its high volatility, persistence, and bio-accumulation, mercury has become one of the most important Hazardous Trace Elements (HTEs), causing a range of diseases [13,14]. Carbon dioxide and nitrous oxide, the main emissions from coal-fired powerplants, are Greenhouse Gases (GHG). The amount of production, depending on the type of coal, is between 23.7$28.5 \mathrm{~g} \mathrm{C}$ per MJ [15]. Therefore, legislation is becoming more stringent, requiring power providers or utility companies to either construct state-of-the-art, advanced powerplants, or to retrofit pollution control technologies into existing facilities. Investment in pollution control technologies is necessary to ensure the continued and reliable supply of electricity while reducing detrimental environmental impacts.

Pollution control technologies can have an impact on emissions and water and energy consumption at the same time [16-18]. Limestone-gypsum wet Flue Gas Desulphurization (FGD), Selective Catalytic Reduction (SCR), and Electrostatic Precipitators (ESP) are the most mature and widely applied end-of-pipe treatment processes against $\mathrm{SO}_{2}, \mathrm{NO}_{x}$, soot, and ashes, respectively [19-22]. It is estimated that $1 \mathrm{~kg}$ of $\mathrm{SO}_{2}$ emission reduction is accompanied by an extra generation of $4.64 \mathrm{~kg} \mathrm{CO}_{2}$ and $0.016 \mathrm{~kg} \mathrm{NO}$. Meanwhile, $1 \mathrm{~kg} \mathrm{NO}$ emission reduction is accompanied by an extra generation of $1.88 \mathrm{~kg} \mathrm{CO}_{2}$ and $0.008 \mathrm{~kg} \mathrm{SO}_{2}$ [23]. The limestone-gypsum wet flue gas desulfurization technology (LGM) consumes a significant $60-80 \mathrm{t} / \mathrm{h}$ of water for a $600 \mathrm{MW}$ generator, and also reduces boiler efficiency [24,25]. Most ammonia-based SCR systems use anhydrous ammonia $\left(\mathrm{NH}_{3}\right)$ as the reducing agent. However, due to the hazards of storing and handling $\mathrm{NH}_{3}$, many systems use aqueous ammonia [26]. Energy is required to provide an electrical charge and to overcome the pressure drop in ESP. It also has significant roles for increasing the efficiency of ESP and Fabric Filters (FF) [27]. Most of the existing studies investigate $\mathrm{CO}_{2}$ postcombustion capture configurations as the most suitable choice for GHG controlling. Aminebased chemical absorption is the most widely investigated option since it is the most mature carbon capture and storage (CCS) technology at present [28]. Regeneration step of aminebased process imposes severe energy, environmental impact, and cost penalties [29-31]. Mercury in flue gas from coal-fired powerplant is present in three forms: elemental mercury $\left(\mathrm{Hg}^{0}\right)$, oxidized mercury $\left(\mathrm{Hg}^{2+}\right)$, and particulate-bound mercury $\left(\mathrm{Hg}_{\mathrm{P}}\right)[32] . \mathrm{Hg}^{2+}$ can be easily captured by wet FGD devices because of its high solubility in water. $\mathrm{Hg}_{\mathrm{P}}$ can be removed via dust control units, such as electrostatic precipitators (ESP) or fabric filters (FF) [33]. Therefore, increasing or decreasing the efficiency of FGD and ESP would affect the amount of total mercury removal. Currently, the Activated Carbon Injection (ACI)-based adsorption process is considered as one of the most effective technologies for $\mathrm{Hg}^{0}$ removal because of its high removal efficiency [34,35]. Nevertheless, the main disadvantages of ACI adsorption technology include its high operation costs and adsorbent loss [36].

Nonetheless, end-of-pipe treatments are still an indispensable approach to reducing environmental stress and focusing on them individually would lead to "pollutant-bypollutant" features [37]. While the underlying assumption of this approach is to protect the whole system by protecting its parts individually, the risk of the environmental problem shifting between these interlinked parts arises. Kim and van Asselt (2016) defined the problem shifting to occur when "a solution for one problem backfires and generates one or more new problems at different times or locations" [37]. Possibly the most prominent example of environmental problem shifting is the Montreal Protocol. By promoting the substitution of ozone-depleting substances with potent greenhouse gas emitting Hydrofluorocarbons (HFCs), the problems with regards to climate change are simply shifted. Another prominent example is the substitution of gasoline with biofuels, shifting the environmental 
impacts from greenhouse gas emissions towards inter-alia increased eutrophication and water consumption [38]. Capaz et al. (2020) pointed at "the environmental trade-offs" of promoting plant-based renewable jet fuels to decrease aviation emissions, showing that they cause higher terrestrial acidification and air pollution than kerosene [39]. Another example is the environmental impacts of ocean fertilization, which aims to enhance the oceans' capacity as a carbon sink by stimulating the growth of plankton, but causes ocean acidification and disruptions of the global carbon cycle [40]. In addition, actions to mitigate environmental impacts often burden already-marginalized communities disproportionately, creating additional social problems out of environmental ones [41]. However, to increase its feasibility, this article focuses solely on environmental problem shifting.

Life Cycle Assessment (LCA) has been proved to be useful for formulating recommendations about systems to reduce the problem shifting issue [42]. Nevertheless, most of the existing research related to the environmental assessment of coal-fired powerplants using the LCA method have focused on comparing the environmental impacts of electricity production with different technologies [43-45]. Many LCA practitioners have only considered CCS due to growing climate change concerns [46-49]. Various efforts have been made to introduce the LCA methodology to assess pollutant end-of-pipe treatment, such as SCR and FGD $[50,51]$. However, while achievements have been made in assessing the environmental performance of end-of-pipe treatment processes, reliable results of their inter-independent relationships remain very limited. None of the previous studies mention problem shifting of emission control systems in coal-fired powerplants. The present study evaluates the overall environmental impact caused by changing the efficiency of various pollution control systems for coal-fired powerplants. This work reveals both positive and negative impacts on the system as a whole by modifying the operation of one unit. The research results will help environmental policymakers to better understand the overall environmental perspective and help the creation of appropriate policies and regulations.

\section{Methodology}

The objective of this research is to evaluate the overall environmental impact by the varying efficiency of pollution prevention systems in coal-fired powerplants, using the procedures of factorial design, linear regression, and the LCA method. The boundaries of this research cover two types of net $650 \mathrm{MW}$ Pulverized Coal (PC) powerplants: supercritical and ultra-supercritical, both with and without carbon capture units. The considered pollution control units of the representative system are Low $\mathrm{NO}_{\mathrm{x}}$ burners and Over Fired Air (LNB \& OFA), SCR, ESP, FGD, and ACI. The data used in the study were extracted from the Integrated Environmental Control Model (IECM). IECM was developed for the US Department of Energy's National Energy Technology Laboratory (NETL) and has been used by various studies as an environmental and energy management tool for powerplants [52-55]. Figure 1 depicts the schematic model of the present study. Bituminous coal (1) is burned to generate heat in a furnace. (2) LNB replaces the upper coal nozzle of the standard two-nozzle cell burner with a secondary air-port. The LNB operates on the principle of staged combustion to reduce $\mathrm{NO}_{x}$ emissions. Highly purified water which is pumped through pipes inside the furnace is turned into steam by the heat. Steam drives a turbine generator (3) to produce electricity which is fed to the transmission system. Cool water from the cooling tower (4) is pumped through a network of tubes running through the condenser. The cool water in the tubes converts the steam back into water to be used again by the plant. While fly ash is deposited from the furnace, flue gas is sent to the ammonia base SCR (5) to remove $\mathrm{NO}_{x}$. Hot flue gas is passed through the air heater (6), which transfers excess heat with input air before being sent to the ACI unit (7). Next, flue gas is sent to ESP (8), FGD (9), and $\mathrm{CO}_{2}$ post-combustion capture units, respectively, before being emitted from the stack (11). 


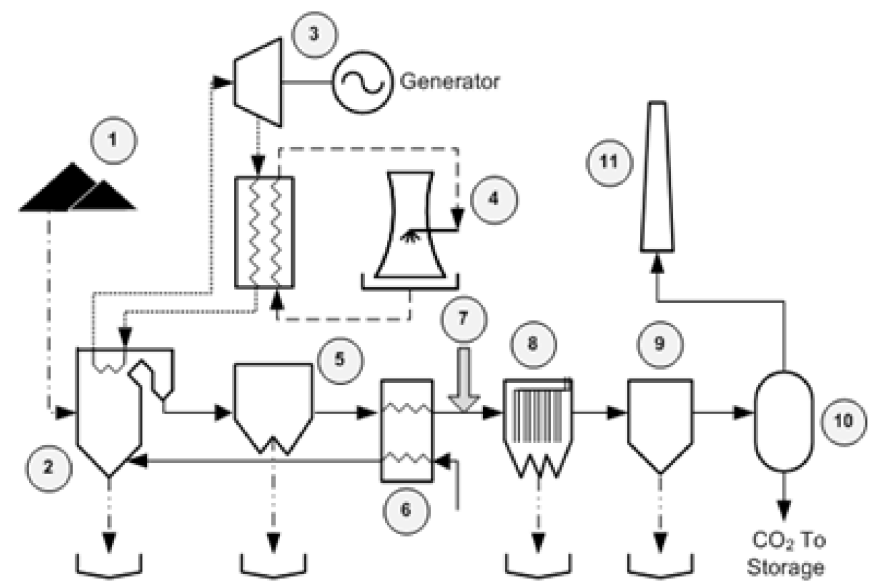

Figure 1. Plant configuration.

Tables 1-3 presents the main configuration of the plant simulation.

Table 1. Plant design configuration.

\begin{tabular}{ccc}
\hline & Combustion Controls & \\
\hline $\begin{array}{c}\text { Fuel Type Coal } \\
\mathrm{NO}_{\mathrm{x}} \text { Control }\end{array}$ & $\begin{array}{c}\text { Coal } \\
\end{array}$ & In-Furnace Controls \\
\hline & Post-Combustion Controls \\
\hline $\mathrm{NO}_{\mathrm{x}}$ Control & Hot-Side SCR \\
Mercury & Carbon Injection \\
Particulates & Cold-Side ESP \\
$\mathrm{SO}_{2}$ Control & Wet FGD \\
$\mathrm{CO}_{2}$ Capture & Amine System \\
\hline & Water and Solids Management \\
\hline Cooling System & Wet Cooling Tower \\
Wastewater & Ash Pond \\
Fly Ash Disposal & No Mixing \\
\hline
\end{tabular}

Table 2. Overall plant performance.

\begin{tabular}{cc}
\hline Gross Electrical Output (MW) & 650 \\
Capacity Factor (\%) & 85 \\
Ambient Air Temp. $\left({ }^{\circ} \mathrm{C}\right)$ & 27.91 \\
Ambient Pressure (MPa) & 0.1013 \\
Relative Humidity (\%) & 73 \\
\hline
\end{tabular}

Table 3. Coal properties.

\begin{tabular}{cc}
\hline Coal Rank & Sub-Bituminous \\
Coal Name & Wyodak-Anderson \\
High Heating Value $(\mathrm{kJ} / \mathrm{kg})$ & $1.96 \times 10^{4}$ \\
Carbon $(\mathrm{wt} \%)$ & 49.21 \\
Hydrogen $(\mathrm{wt} \%)$ & 3.51 \\
Oxygen $(\mathrm{wt} \%)$ & 11.67 \\
Sulfur $(\mathrm{wt} \%)$ & 0.45 \\
Nitrogen $(\mathrm{wt} \%)$ & 0.73 \\
Ash $(\mathrm{wt} \%)$ & 6.31 \\
Moisture $(\mathrm{wt} \%)$ & 28.09 \\
\hline
\end{tabular}


The studied variables in this research were classified into independent and dependent variables, as shown in Tables 4 and 5. The simulation was divided into four sets, based on the supercritical or ultra-supercritical systems, and either with or without the carbon capture unit. Full 2-level factorial design of individual interaction was applied to each set of the simulation to determine the number of simulation runs and independent variable for each run, using Design of Experiment (DOE) and the factorial design function of the Minitab software. The number of simulation runs for each simulation set are presented as a matrix in Table 6. Each simulation was processed using the IECM software by changing the independent variables (x1-x6) according to the DOE result. Each dependent variable (y1-y12) for each run was recorded. Multiple regression analysis was applied to generate relationships and their influence between the independent and dependent variables, using data analysis in the Excel software with a 95\% confidence level. The regression results reveal the various coefficients of linear equation, which represent the influence of pollution controlling efficiency to raw material consumption and emission, as shown in Equation (1) to Equation (4):

$$
\begin{gathered}
y_{1}=b_{11} x_{1}+b_{12} x_{2}+b_{13} x_{3}+\ldots+b_{1 j} x_{j}+\ldots+b_{1 n} x_{n}+c_{1} \\
\vdots \\
y_{i}=b_{i 1} x_{1}+b_{i 2} x_{2}+b_{i 3} x_{3}+\ldots+b_{i j} x_{j}+\ldots+b_{i n} x_{n}+c_{i} \\
\vdots \\
y_{m}=b_{m 1} x_{1}+b_{m 2} x_{2}+b_{m 3} x_{3}+\ldots+b_{m j} x_{j}+\ldots+b_{m n} x_{n}+c_{m} \\
y_{i}=\sum_{j=1}^{n}\left(b_{i j} x_{j}+c_{i}\right) \\
\Delta y_{i}=\sum_{j=1}^{n}\left(b_{i j} \Delta x_{j}+c_{i}\right) \\
\Delta y_{i j}=b_{i j}
\end{gathered}
$$

where

$\mathrm{y}_{\mathrm{i}}=$ Dependent variable $\mathrm{i}$

$\Delta y_{i}=$ Total change of dependent variable i

$\Delta y_{i j}=$ Shifting of dependent variable i per 1 percent changing of $\Delta x_{j}$

$x_{j}=$ Independent variable $j$

$\Delta \mathrm{x}_{\mathrm{j}}=$ Shifting of independent variable $\mathrm{j}$

\begin{tabular}{|c|c|c|}
\hline & Independent Variable & Range (Min-Max), A or N/A \\
\hline $\mathbf{x 1}$ & Efficiency of in-furnace $\mathrm{NO}_{\mathrm{x}}$ control system (\%) [56] & $60-65$ \\
\hline$x 2$ & Efficiency of $\mathrm{NO}_{x}$ control by SCR (\%) [57] & $80-90$ \\
\hline$x 3$ & Efficiency of PM control by ESP (\%) [58] & $95-99.9$ \\
\hline$x 4$ & Efficiency of $\mathrm{SO}_{2}$ control by FGD (\%) [59] & $95-98$ \\
\hline$x 5$ & Mercury control by carbon injection $(\%)$ & $\mathrm{N} / \mathrm{A} *$ or completely removed \\
\hline$x 6$ & Efficiency of $\mathrm{CO}_{2}$ control by MEA absorption (\%) [60] & $\mathrm{A}^{*}$ or $\mathrm{N} / \mathrm{A}, 90-96$ \\
\hline
\end{tabular}

$\mathrm{b}_{\mathrm{ij}}=$ Regression coefficient

$c_{\mathrm{i}}=$ Intersection $\mathrm{i}$

$\mathrm{m}=$ Number of dependent variables

$\mathrm{n}=$ Number of independent variables.

Table 4. Independent variables.

${ }^{*} \mathrm{~A}$ is available. N/A is not available. 
Table 5. Dependent variables.

\begin{tabular}{|c|c|c|}
\hline \multicolumn{2}{|c|}{ Dependent Variable } & Unit \\
\hline \multicolumn{3}{|c|}{ Input } \\
\hline y1 & Electrical consumption & MW \\
\hline $\mathrm{y}^{2}$ & Coal consumption & ton $/ \mathrm{h}$ \\
\hline y3 & Limestone consumption & ton $/ \mathrm{h}$ \\
\hline y4 & MEA consumption & ton $/ \mathrm{h}$ \\
\hline y5 & Ammonia consumption & ton $/ \mathrm{h}$ \\
\hline y6 & Activated carbon consumption & ton $/ \mathrm{h}$ \\
\hline y7 & Makeup water & ton $/ \mathrm{h}$ \\
\hline \multicolumn{3}{|c|}{ Output } \\
\hline y8 & $\mathrm{CO}_{2}$ emission & $\mathrm{kg} / \mathrm{h}$ \\
\hline y9 & $\mathrm{SO}_{2}$ emission & $\mathrm{kg} / \mathrm{h}$ \\
\hline y10 & $\mathrm{NO}_{2}$ emission & $\mathrm{kg} / \mathrm{h}$ \\
\hline y11 & PM emission & $\mathrm{kg} / \mathrm{h}$ \\
\hline y12 & Mercury emission & $\mathrm{kg} / \mathrm{h}$ \\
\hline
\end{tabular}

Table 6. Simulation sets and runs.

\begin{tabular}{ccc}
\hline \multirow{2}{*}{ Type of System } & \multicolumn{2}{c}{ Number of Independent Variable/Number of Runs } \\
\cline { 2 - 3 } & With Carbon Capture Unit & Without Carbon Capture Unit \\
\hline Supercritical & $6 / 64$ (Set 1) & $5 / 32($ Set 3) \\
Ultra-supercritical & $6 / 64$ (Set 2) & $5 / 32$ Set 4$)$ \\
\hline
\end{tabular}

The ISO/44 framework was adopted as the LCA methodology in this study. The goal of this study was to determine the influence of changing pollution control system efficiency on the environmental and human health impacts. The LCA inventory includes the related resources or energy inputs and the environmental emissions (dependent variable) from six pollution control units (LNB \& OFA, SCR, ESP, FGD, ACI, and CCS). In this study, the impact of waste management is excluded. The reference flow of this study is 1 percent of the pollution control efficiency changes in a net $650 \mathrm{MW}$ PC power plant. The regression coefficients of each run, $b_{i j}$, which represent the effect of increasing 1 percent efficiency of pollution control unit $j$ on the input-output variable $i$, were exported to the SimaPro LCA software for LCA analysis. The ReCiPe mid-point and end-point (H) V1.02 method-a recent and well-established model — was used to assess acidification (ADP), human toxicity (HT), particulate matter formation (PM), and water depletion (WD). For the climate change impact (GWP), IPCC 2007 GWP 100a V1.02 was used for the impact assessment. The total change of the environmental impact for any category $\mathrm{k}$ by changing the independent variable $\mathrm{j}$ can be evaluated using Equation (5):

$$
\Delta \mathrm{I}_{\mathrm{kj}}=\sum_{\mathrm{i}=1}^{\mathrm{m}}\left(\mathrm{b}_{\mathrm{ij}} \times \mathrm{EF}_{\mathrm{ik}}\right)
$$

where

$\Delta \mathrm{I}_{\mathrm{kj}}=$ Shifting of the environmental impact k per 1 percent change of $\Delta \mathrm{x}_{\mathrm{j}}$

$\mathrm{EF}_{\mathrm{ik}}=$ Determined emission environmental impact factor of dependent variable $\mathrm{i}$.

\section{Results and Discussion}

Tables 7-10 show the regression results for all four of the studied scenarios. The coefficients in the tables show the relationships between the variable percentage for the removal of the pollution control units and the effects on the various dependent variables. In this case, the coefficients with a $p$-value greater than 0.05 were considered as a nonsignificant coefficient and assigned to be approximately zero $(\approx 0)$. The final column indicates the maximum and minimum value of the associated dependent variable in the range of the independent variable. The minimum value for each dependent variable 
was obtained when the positive coefficients were at their minimum, while the negative coefficients were at their maximum. For instance, to minimize the electricity consumption of the ultra-supercritical powerplant with a $\mathrm{CO}_{2}$ capture unit, the removal percent of $\mathrm{NO}_{x}$ control by SCR, $\mathrm{PM}, \mathrm{SO}_{2}$, mercury, and $\mathrm{CO}_{2}$ should be set to $80,95,95,0$, and 90, respectively, while in the furnace, the $\mathrm{NO}_{\mathrm{x}}$ efficiency was 65. At first glance, the results in Tables 7-10 indicate that for powerplants with carbon capture units-whether ultra-supercritical or supercritical-increasing the carbon dioxide removal percentage has positive impacts on almost every dependent variable. However, changing the removal percent of PM control unit $\left(b_{i, 3}\right)$ is not significantly affect to dependent variables (excluded amount of PM emission, which changes according to the percentage removal), the removal percent of the furnace $\mathrm{NO}_{x}$ control unit $\left(b_{i, 1}\right)$ exhibiting a negative trend effect. Without a carbon capture unit, the most positive significant role-playing parameter was changing the percent removal of the FGD unit $\left(b_{i, 4}\right)$, while the removal percent of the furnace $\mathrm{NO}_{\mathrm{x}}$ control unit $\left(b_{i, 1}\right)$ still had negative effects on a few important dependent variables. However, the effect of changing the percent removal on all dependent variables was weaker when the supercritical plant was applied.

Table 7. Regression coefficient of an ultra-supercritical powerplant with a $\mathrm{CO}_{2}$ capture unit.

\begin{tabular}{|c|c|c|c|c|c|c|c|c|}
\hline $\begin{array}{c}\text { Dependent } \\
\text { Variable }\end{array}$ & $b_{i, 1}$ & $b_{i, 2}$ & $b_{i, 3}$ & $b_{i, 4}$ & $b_{i, 5}$ & $b_{i, 6}$ & Interc. & Max/Min \\
\hline $\mathrm{y}_{1}(\mathrm{MW})$ & $-8.1 \times 10^{-3}$ & $3.4 \times 10^{-3}$ & $1.6 \times 10^{-1}$ & 1.5 & $1.3 \times 10^{-1}$ & 1.2 & $-1.2 \times 10^{2}$ & $149.3 / 162.0$ \\
\hline $\mathrm{y}_{2}(\mathrm{~T} / \mathrm{h})$ & $\approx 0$ & $\approx 0$ & $\approx 0$ & $\approx 0$ & $\approx 0$ & 1.4 & $2.2 \times 10^{2}$ & $347.5 / 355.8$ \\
\hline $\mathrm{y}_{3}(\mathrm{~T} / \mathrm{h})$ & $4.5 \times 10^{-4}$ & $-6.7 \times 10^{-4}$ & $\approx 0$ & $4.8 \times 10^{-2}$ & $\approx 0$ & $1.8 \times 10^{-2}$ & -1.6 & $4.482 / 4.743$ \\
\hline $\mathrm{y}_{4}(\mathrm{~T} / \mathrm{h})$ & $-4.5 \times 10^{-4}$ & $\approx 0$ & $\approx 0$ & $-2.6 \times 10^{-2}$ & $\approx 0$ & $1.9 \times 10^{-2}$ & 2.3 & $1.392 / 1.585$ \\
\hline $\mathrm{y}_{5}(\mathrm{~T} / \mathrm{h})$ & $-8.3 \times 10^{-3}$ & $3.7 \times 10^{-3}$ & $\approx 0$ & $\approx 0$ & $\approx 0$ & $1.2 \times 10^{-3}$ & $4.1 \times 10^{-1}$ & $0.2737 / 0.3592$ \\
\hline $\mathrm{y}_{6}(\mathrm{~T} / \mathrm{h})$ & $-1.1 \times 10^{-5}$ & $5.4 \times 10^{-6}$ & $\approx 0$ & $2.8 \times 10^{-6}$ & $1.5 \times 10^{-1}$ & $9.5 \times 10^{-4}$ & $-4.4 \times 10^{-2}$ & $0.0424 / 0.2021$ \\
\hline$y_{7}(\mathrm{~kg} / \mathrm{h})$ & $-1.3 \times 10^{-1}$ & $6.4 \times 10^{-2}$ & $\approx 0$ & $-1.9 \times 10^{-1}$ & $\approx 0$ & 7.9 & $1.4 \times 10^{3}$ & $2052 / 2102$ \\
\hline$y_{8}(\mathrm{~kg} / \mathrm{h})$ & $9.1 \times 10^{-1}$ & $-3.6 \times 10^{-1}$ & $\approx 0$ & 1.0 & $\approx 0$ & $-6.2 \times 10^{3}$ & $6.2 \times 10^{5}$ & $25,737 / 62,845$ \\
\hline $\mathrm{y}_{9}(\mathrm{~kg} / \mathrm{h})$ & $-4.6 \times 10^{-4}$ & $8.7 \times 10^{-4}$ & $5.2 \times 10^{-5}$ & $-4.1 \times 10^{-2}$ & $2.6 \times 10^{-4}$ & $1.5 \times 10^{-3}$ & 4.2 & $0.3233 / 0.4683$ \\
\hline $\mathrm{y}_{10}(\mathrm{~kg} / \mathrm{h})$ & -3.9 & -9.8 & $\approx 0$ & $1.3 \times 10^{-3}$ & $\approx 0$ & $5.8 \times 10^{-1}$ & $1.2 \times 10^{3}$ & $90.09 / 210.8$ \\
\hline $\mathrm{y}_{11}(\mathrm{~kg} / \mathrm{h})$ & $\approx 0$ & $\approx 0$ & $-3.9 \times 10^{1}$ & $\approx 0$ & $9.8 \times 10^{-1}$ & $4.0 \times 10^{-1}$ & $3.9 \times 10^{3}$ & $3.871 / 200.1$ \\
\hline $\mathrm{y}_{12}(\mathrm{~kg} / \mathrm{h})$ & $\approx 0$ & $\approx 0$ & $\approx 0$ & $\approx 0$ & $-8.9 \times 10^{-3}$ & $4.5 \times 10^{-5}$ & $1.2 \times 10^{-2}$ & $0.0069 / 0.0161$ \\
\hline
\end{tabular}

Table 8. Regression coefficient of a supercritical powerplant with a $\mathrm{CO}_{2}$ capture unit.

\begin{tabular}{|c|c|c|c|c|c|c|c|c|}
\hline $\begin{array}{l}\text { Dependent } \\
\text { Variable }\end{array}$ & $b_{i, 1}$ & $b_{i, 2}$ & $b_{i, 3}$ & $b_{i, 4}$ & $b_{i, 5}$ & $\mathbf{b}_{\mathrm{i}, 6}$ & Interc. & Max/Min \\
\hline $\mathrm{y}_{1}(\mathrm{MW})$ & $-5.0 \times 10^{-3}$ & $2.5 \times 10^{-3}$ & $1.6 \times 10^{-1}$ & 1.7 & $1.3 \times 10^{-1}$ & 1.4 & $-1.4 \times 10^{2}$ & $166.9 / 181.4$ \\
\hline $\mathrm{y}_{2}(\mathrm{~T} / \mathrm{h})$ & $5.0 \times 10^{-3}$ & $-2.5 \times 10^{-3}$ & $\approx 0$ & $\approx 0$ & $\approx 0$ & 1.8 & $2.3 \times 10^{2}$ & $391.7 / 402.3$ \\
\hline $\mathrm{y}_{3}(\mathrm{~T} / \mathrm{h})$ & $4.5 \times 10^{-4}$ & $-7.0 \times 10^{-4}$ & $\approx 0$ & $5.4 \times 10^{-2}$ & $\approx 0$ & $2.3 \times 10^{-2}$ & -2.1 & $5.053 / 5.362$ \\
\hline $\mathrm{y}_{4}(\mathrm{~T} / \mathrm{h})$ & $-5.5 \times 10^{-4}$ & $\approx 0$ & $\approx 0$ & $-2.9 \times 10^{-2}$ & $\approx 0$ & $2.2 \times 10^{-2}$ & 2.5 & $1.569 / 1.793$ \\
\hline $\mathrm{y}_{5}(\mathrm{~T} / \mathrm{h})$ & $-9.4 \times 10^{-3}$ & $4.1 \times 10^{-3}$ & $\approx 0$ & $\approx 0$ & $\approx 0$ & $1.6 \times 10^{-3}$ & $4.4 \times 10^{-1}$ & $0.3083 / 0.4061$ \\
\hline $\mathrm{y}_{6}(\mathrm{~T} / \mathrm{h})$ & $-1.2 \times 10^{-5}$ & $6.0 \times 10^{-6}$ & $\approx 0$ & $8.3 \times 10^{-7}$ & $1.7 \times 10^{-1}$ & $1.1 \times 10^{-3}$ & $-5.6 \times 10^{-2}$ & $0.0478 / 0.2285$ \\
\hline $\mathrm{y}_{7}(\mathrm{~kg} / \mathrm{h})$ & $-1.3 \times 10^{-1}$ & $6.3 \times 10^{-2}$ & $\approx 0$ & $-2.0 \times 10^{-1}$ & $\approx 0$ & $1.1 \times 10^{1}$ & $1.5 \times 10^{3}$ & $2494 / 2561$ \\
\hline $\mathrm{y}_{8}(\mathrm{~kg} / \mathrm{h})$ & $8.8 \times 10^{-1}$ & $-4.4 \times 10^{-1}$ & $\approx 0$ & 1.7 & $\approx 0$ & $-7.0 \times 10^{3}$ & $7.0 \times 10^{5}$ & $29,099 / 70,844$ \\
\hline $\mathrm{y}_{9}(\mathrm{~kg} / \mathrm{h})$ & $-5.2 \times 10^{-4}$ & $9.8 \times 10^{-4}$ & $5.9 \times 10^{-5}$ & $-4.7 \times 10^{-2}$ & $2.9 \times 10^{-4}$ & $1.9 \times 10^{-3}$ & 4.7 & $0.3645 / 0.5294$ \\
\hline $\mathrm{y}_{10}(\mathrm{~kg} / \mathrm{h})$ & -4.4 & $-1.1 \times 10^{1}$ & $\approx 0$ & $1.1 \times 10^{-3}$ & $\approx 0$ & $7.3 \times 10^{-1}$ & $1.3 \times 10^{3}$ & $101.58 / 238.36$ \\
\hline$y_{11}(\mathrm{~kg} / \mathrm{h})$ & $\approx 0$ & $\approx 0$ & $-4.4 \times 10^{1}$ & $\approx 0$ & 1.1 & $5.0 \times 10^{-1}$ & $4.4 \times 10^{3}$ & $4.364 / 226.3$ \\
\hline $\mathrm{y}_{12}(\mathrm{~kg} / \mathrm{h})$ & $\approx 0$ & $\approx 0$ & $\approx 0$ & $\approx 0$ & $-1.0 \times 10^{-2}$ & $5.8 \times 10^{-5}$ & $1.3 \times 10^{-2}$ & $0.0078 / 0.0182$ \\
\hline
\end{tabular}


Table 9. Regression coefficient of an ultra-supercritical powerplant without a $\mathrm{CO}_{2}$ capture unit.

\begin{tabular}{|c|c|c|c|c|c|c|c|}
\hline $\begin{array}{c}\text { Dependent } \\
\text { Variable }\end{array}$ & $b_{i, 1}$ & $b_{i, 2}$ & $b_{i, 3}$ & $\mathbf{b}_{\mathrm{i}, 4}$ & $\mathbf{b}_{\mathrm{i}, 5}$ & Interc. & Max/Min \\
\hline $\mathrm{y}_{1}(\mathrm{MW})$ & $\approx 0$ & $\approx 0$ & $1.6 \times 10^{-1}$ & 1.2 & $8.8 \times 10^{-2}$ & $-7.9 \times 10^{1}$ & $46.8 / 51.2$ \\
\hline $\mathrm{y}_{2}(\mathrm{~T} / \mathrm{h})$ & $\approx 0$ & $\approx 0$ & $\approx 0$ & $\approx 0$ & $\approx 0$ & $2.7 \times 10^{2}$ & 273.5 \\
\hline $\mathrm{y}_{3}(\mathrm{~T} / \mathrm{h})$ & $2.5 \times 10^{-4}$ & $-4.2 \times 10^{-4}$ & $\approx 0$ & $3.7 \times 10^{-2}$ & $\approx 0$ & $2.8 \times 10^{-2}$ & $3.528 / 3.645$ \\
\hline $\mathrm{y}_{4}(\mathrm{~T} / \mathrm{h})$ & - & - & - & - & - & - & $-/-$ \\
\hline $\mathrm{y}_{5}(\mathrm{~T} / \mathrm{h})$ & $-6.5 \times 10^{-3}$ & $2.8 \times 10^{-3}$ & $\approx 0$ & $\approx 0$ & $\approx 0$ & $4.1 \times 10^{-1}$ & $0.2154 / 0.2761$ \\
\hline $\mathrm{y}_{6}(\mathrm{~T} / \mathrm{h})$ & $-5.0 \times 10^{-6}$ & $2.5 \times 10^{-6}$ & $\approx 0$ & $\approx 0$ & $1.2 \times 10^{-1}$ & $1.0 \times 10^{-4}$ & $0 / 0.1197$ \\
\hline $\mathrm{y}_{7}(\mathrm{~kg} / \mathrm{h})$ & $\approx 0$ & $\approx 0$ & $\approx 0$ & $\approx 0$ & $\approx 0$ & $1.4 \times 10^{3}$ & $1461 / 1459$ \\
\hline $\mathrm{y}_{8}(\mathrm{~kg} / \mathrm{h})$ & $\approx 0$ & $\approx 0$ & $\approx 0$ & $\approx 0$ & $\approx 0$ & $4.9 \times 10^{5}$ & $494,567 / 494,550$ \\
\hline $\mathrm{y}_{9}(\mathrm{~kg} / \mathrm{h})$ & $-6.4 \times 10^{-2}$ & $1.3 \times 10^{-1}$ & $\approx 0$ & $-2.1 \times 10^{1}$ & $\approx 0$ & $2.1 \times 10^{3}$ & $50.90 / 116.20$ \\
\hline $\mathrm{y}_{10}(\mathrm{~kg} / \mathrm{h})$ & -3.1 & -7.7 & $\approx 0$ & $\approx 0$ & $\approx 0$ & $9.6 \times 10^{2}$ & $71.77 / 164.12$ \\
\hline $\mathrm{y}_{11}(\mathrm{~kg} / \mathrm{h})$ & $\approx 0$ & $\approx 0$ & $-6.1 \times 10^{1}$ & $\approx 0$ & 1.5 & $6.1 \times 10^{3}$ & $6.094 / 307.6$ \\
\hline $\mathrm{y}_{12}(\mathrm{~kg} / \mathrm{h})$ & $\approx 0$ & $\approx 0$ & $\approx 0$ & $\approx 0$ & $-6.9 \times 10^{-3}$ & $1.2 \times 10^{-2}$ & $0.0054 / 0.0124$ \\
\hline
\end{tabular}

Table 10. Regression coefficient of an ultra-supercritical powerplant without a $\mathrm{CO}_{2}$ capture unit.

\begin{tabular}{|c|c|c|c|c|c|c|c|}
\hline $\begin{array}{l}\text { Dependent } \\
\text { Variable }\end{array}$ & $b_{i, 1}$ & $b_{i, 2}$ & $\mathbf{b}_{\mathrm{i}, 3}$ & $b_{i, 4}$ & $b_{i, 5}$ & Interc. & Max/Min \\
\hline $\mathrm{y}_{1}$ (MW) & $\approx 0$ & $\approx 0$ & $1.6 \times 10^{-1}$ & 1.3 & $1.0 \times 10^{-1}$ & $-8.5 \times 10^{1}$ & $51.3 / 55.9$ \\
\hline $\mathrm{y}_{2}(\mathrm{~T} / \mathrm{h})$ & $\approx 0$ & $\approx 0$ & $\approx 0$ & $\approx 0$ & $\approx 0$ & $3.0 \times 10^{2}$ & 300.2 \\
\hline $\mathrm{y}_{3}(\mathrm{~T} / \mathrm{h})$ & $3.0 \times 10^{-4}$ & $-5.0 \times 10^{-4}$ & $\approx 0$ & $4.1 \times 10^{-2}$ & $\approx 0$ & $5.1 \times 10^{-2}$ & $3.872 / 4.0$ \\
\hline $\mathrm{y}_{4}(\mathrm{~T} / \mathrm{h})$ & - & - & - & - & - & - & $-/-$ \\
\hline $\mathrm{y}_{5}(\mathrm{~T} / \mathrm{h})$ & $-7.1 \times 10^{-3}$ & $3.1 \times 10^{-3}$ & $\approx 0$ & $\approx 0$ & $\approx 0$ & $4.5 \times 10^{-1}$ & $0.2363 / 0.3030$ \\
\hline $\mathrm{y}_{6}(\mathrm{~T} / \mathrm{h})$ & $-1.0 \times 10^{-5}$ & $5.0 \times 10^{-6}$ & $\approx 0$ & $\approx 0$ & $1.3 \times 10^{-1}$ & $2.0 \times 10^{-4}$ & $0 / 1314$ \\
\hline $\mathrm{y}_{7}(\mathrm{~kg} / \mathrm{h})$ & $\approx 0$ & $\approx 0$ & $\approx 0$ & $\approx 0$ & $\approx 0$ & $1.6 \times 10^{3}$ & $1631 / 1627$ \\
\hline $\mathrm{y}_{8}(\mathrm{~kg} / \mathrm{h})$ & $\approx 0$ & $\approx 0$ & $\approx 0$ & $\approx 0$ & $\approx 0$ & $5.4 \times 10^{5}$ & $542,824 / 542,809$ \\
\hline $\mathrm{y}_{9}(\mathrm{~kg} / \mathrm{h})$ & $-7.0 \times 10^{-2}$ & $1.4 \times 10^{-1}$ & $\approx 0$ & $-2.3 \times 10^{1}$ & $\approx 0$ & $2.3 \times 10^{3}$ & $55.87 / 127.54$ \\
\hline $\mathrm{y}_{10}(\mathrm{~kg} / \mathrm{h})$ & -3.4 & -8.4 & $\approx 0$ & $\approx 0$ & $\approx 0$ & $1.1 \times 10^{3}$ & $78.77 / 180.13$ \\
\hline $\mathrm{y}_{11}(\mathrm{~kg} / \mathrm{h})$ & $\approx 0$ & $\approx 0$ & $-6.7 \times 10^{1}$ & $\approx 0$ & 1.7 & $6.7 \times 10^{3}$ & $6.689 / 337.6$ \\
\hline $\mathrm{y}_{12}(\mathrm{~kg} / \mathrm{h})$ & $\approx 0$ & $\approx 0$ & $\approx 0$ & $\approx 0$ & $-7.6 \times 10^{-3}$ & $1.4 \times 10^{-2}$ & $0.0060 / 0.0136$ \\
\hline
\end{tabular}

As mentioned in the results above, an increased $\mathrm{CO}_{2}$ removal percent results in increased use of powerplant resources. This means that some of the electrical energy generated by the powerplant is reduced (more own electricity consumption, $b_{1,6}$ ) due to a portion of heat from the coal combustion being drawn back to be used in the MEA regeneration column in the form of steam. Meanwhile, the decreasing electricity production when increasing the $\mathrm{SO}_{x}$ removal percentage in the FGD unit $\left(\mathrm{b}_{1,4}\right)$ was due to directly using the electricity produced by the powerplant. Since the MEA adsorption unit utilizes energy from steam for solvent regeneration, it is possible to observe the effect of $\mathrm{CO}_{2}$ removal percent on both coal and electricity consumption $\left(b_{2,6}\right.$ and $\left.b_{2,6}\right)$.

Increasing the efficiency of the in-furnace $\mathrm{NO}_{x}$ control resulted in reduced ammonia consumption $\left(b_{5,1}\right)$ due to the reduced $\mathrm{NO}_{\mathrm{x}}$ removal burden at the SCR unit, which uses anhydrous ammonia $\left(\mathrm{NH}_{3}\right)$ as the reducing agent solution. Additionally, increasing the efficiency of the in-furnace $\mathrm{NO}_{x}$ control unit also resulted in a decreased amount of activated carbon used $\left(b_{6,1}\right)$ because activated carbon can absorb both mercury and $\mathrm{NO}_{\mathrm{x}}[61,62]$. Generally, the remaining $\mathrm{NO}_{x}$ from the in-furnace $\mathrm{NO}_{x}$ control and SCR unit, presented in the ACI unit, is the mercury's competitive substance, which causes additional activated carbon requirements. Moreover, the in-furnace $\mathrm{NO}_{\mathrm{x}}$ control unit uses a very small amount of energy $\left(b_{1,1}\right)$ compared to others unit; therefore, the electricity saving effect can be evidently observed. On the other hand, the $\mathrm{NO}_{\mathrm{x}}$ reduction by using the SCR unit efficiently to reduce $\mathrm{NO}_{x}$ consumes more electricity and ammonia $\left(b_{1,2}\right.$ and $\left.b_{5,2}\right)$. Increasing the efficiency of the SCR unit reduces both $\mathrm{NO}_{x}$ and $\mathrm{SO}_{2}\left(\mathrm{~b}_{10,2}\right.$ and $\left.\mathrm{b}_{9,2}\right)$. Consequently, the amount of limestone used in the FGD unit also decreased as the $\mathrm{SO}_{2}$ load decreased. The amount of activated carbon in this case did not decrease because the increased electricity consumption generated more mercury and more activated carbon usage. 
With the $\mathrm{CO}_{2}$ capture scenario, increasing the FGD efficiency resulted in decreased MEA $\left(b_{4,4}\right)$ and makeup water consumption $\left(b_{7,4}\right)$, which are both used in the $\mathrm{CO}_{2} \mathrm{ab}-$ sorption unit. These results can be explained by some of the $\mathrm{CO}_{2}$ also being absorbed by the limestone [63]. The consequence of using activated carbon for mercury removal is the possibility of small particles at the micron level being blown out from the ACI unit to the ESP unit. These small particles interfere with the ESP system and increase the removal load, resulting in the remaining PM being released into the atmosphere.

Shifting of environmental impact $k$ according to a percent changing of variable $j$ can be calculated using Equation (5). The emission factor of the 12 dependent variables are shown in Table 11. The results of each impact category for every scenario are summarized in Figures 2-6.

Table 11. Emission factor of the dependent variables.

\begin{tabular}{|c|c|c|c|c|c|c|}
\hline $\begin{array}{c}\text { Dependent } \\
\text { Variable }\end{array}$ & $\begin{array}{c}\text { GWP } \\
\mathrm{kg} \mathrm{CO} \text {-eq }\end{array}$ & $\begin{array}{c}\text { HT } \\
\text { kg 1,4-DB-eq }\end{array}$ & $\begin{array}{c}\text { PM } \\
\text { kg PM10-eq }\end{array}$ & $\begin{array}{c}\mathrm{ADP} \\
\mathrm{kg} \mathrm{SO} \mathrm{S}_{2} \text {-eq }\end{array}$ & $\begin{array}{l}\text { WD } \\
\mathbf{m}^{3}\end{array}$ & Per Unit \\
\hline $\mathrm{y}_{1}$ & $6.1 \times 10^{2}$ & $2.4 \times 10^{-4}$ & $2.3 \times 10^{-1}$ & $7.2 \times 10^{-2}$ & 0 & MWh \\
\hline $\mathrm{y}_{2}$ & $1.6 \times 10^{2}$ & $5.6 \times 10^{1}$ & $9.7 \times 10^{-2}$ & $3.6 \times 10^{-1}$ & 0 & ton \\
\hline $\mathrm{y}_{3}$ & 6.5 & $5.3 \times 10^{-1}$ & $8.7 \times 10^{-3}$ & $3.2 \times 10^{-2}$ & 0 & ton \\
\hline $\mathrm{y}_{4}$ & $3.4 \times 10^{3}$ & $8.7 \times 10^{2}$ & 4.0 & $1.3 \times 10^{1}$ & $1.0 \times 10^{1}$ & ton \\
\hline $\mathrm{y}_{5}$ & $3.1 \times 10^{2}$ & 0 & $3.4 \times 10^{-2}$ & $9.0 \times 10^{-2}$ & 0 & ton \\
\hline $\mathrm{y}_{6}$ & $3.0 \times 10^{3}$ & $1.2 \times 10^{3}$ & 0 & $5.0 \times 10^{1}$ & 0 & ton \\
\hline $\mathrm{y}_{7}$ & 0 & 0 & 0 & 0 & 1.0 & ton \\
\hline $\mathrm{y}_{8}$ & 1.0 & 0 & 0 & 0 & 0 & $\mathrm{~kg}$ \\
\hline Y9 & 0 & 0 & $2.0 \times 10^{-1}$ & 1.0 & 0 & $\mathrm{~kg}$ \\
\hline $\mathrm{y}_{10}$ & 0 & 0 & $2.2 \times 10^{-1}$ & $5.6 \times 10^{-1}$ & 0 & $\mathrm{~kg}$ \\
\hline $\mathrm{y}_{11}$ & 0 & 0 & 1.0 & 0 & 0 & $\mathrm{~kg}$ \\
\hline $\mathrm{y}_{12}$ & 0 & $5.7 \times 10^{4}$ & 0 & 0 & 0 & $\mathrm{~kg}$ \\
\hline
\end{tabular}

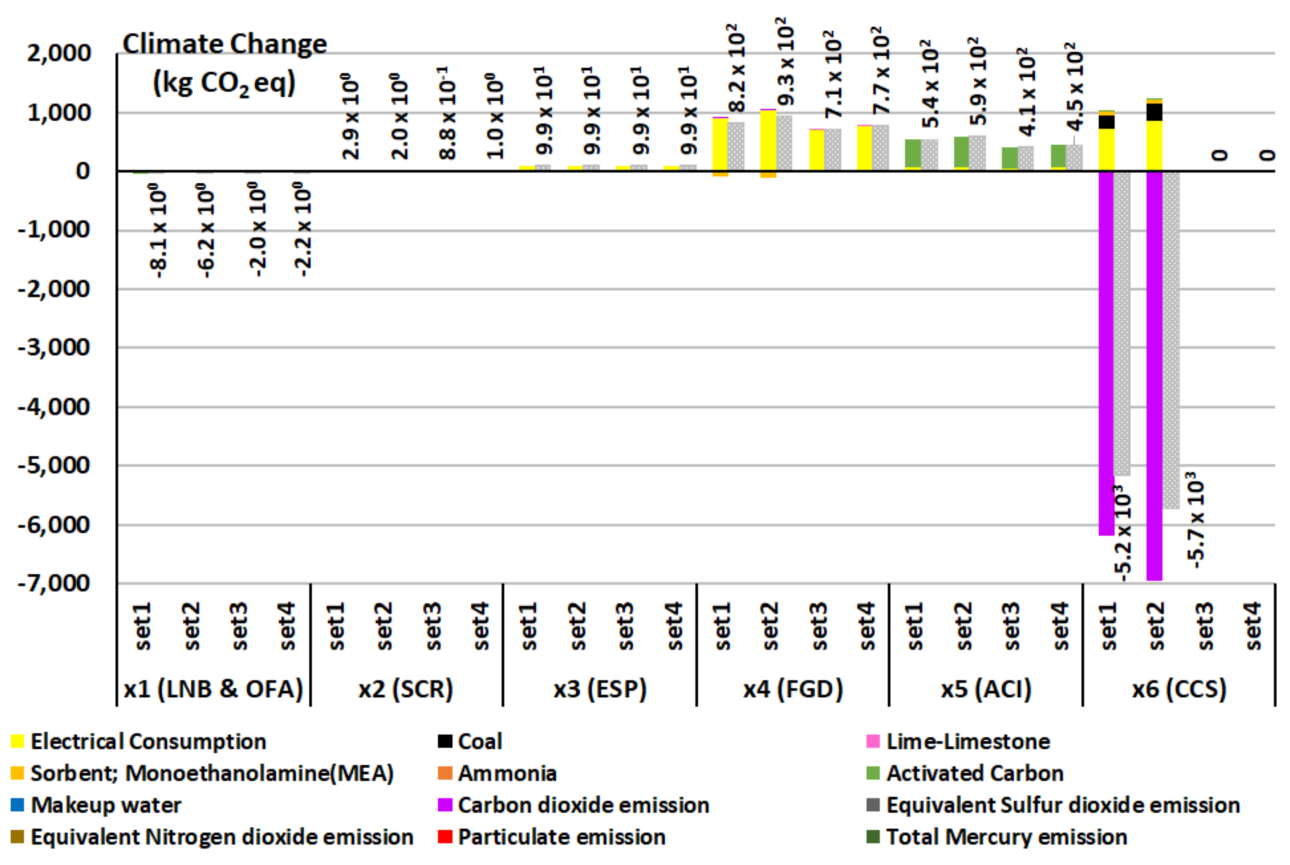

Figure 2. GWP impact of each pollution control unit per increasing percent of performance. 


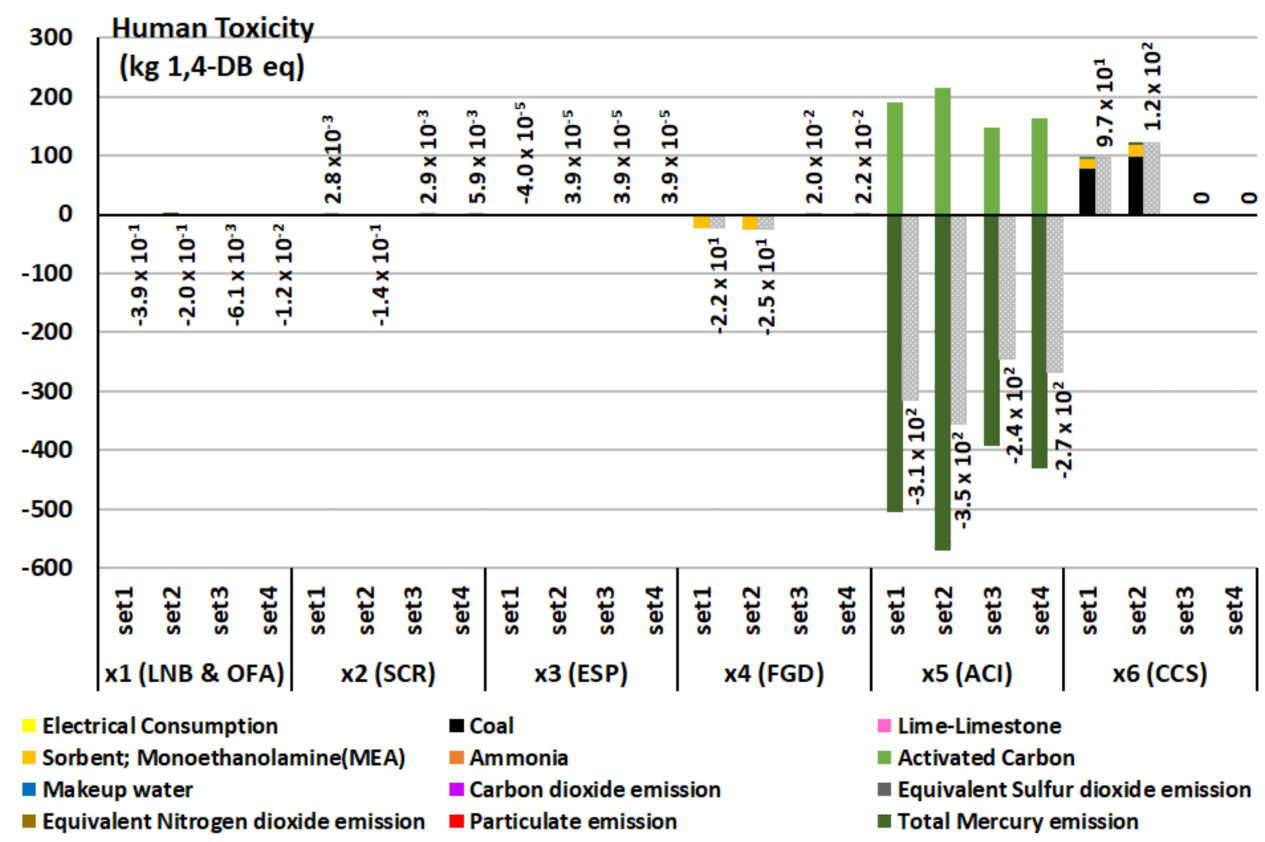

Figure 3. HT impact of each pollution control unit per increasing percent of performance.

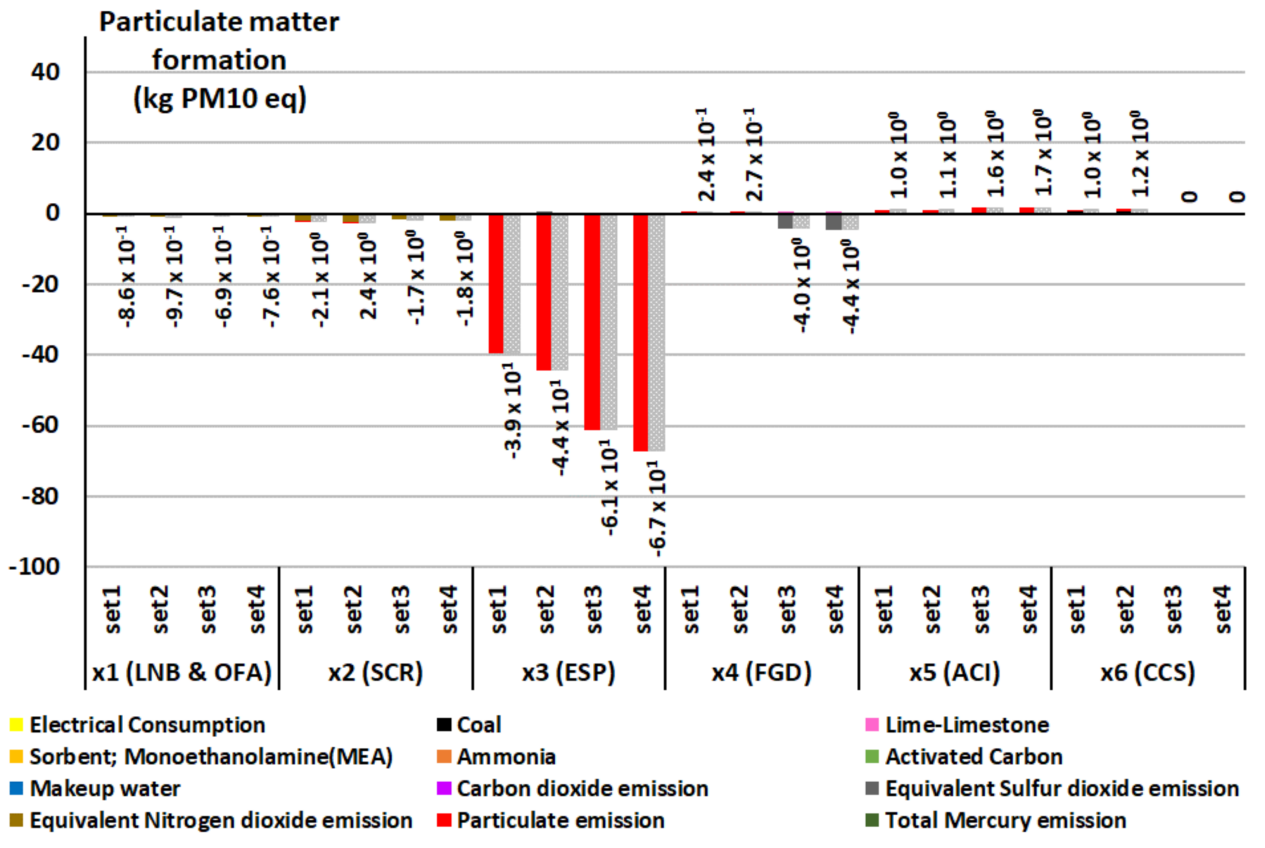

Figure 4. PM impact of each pollution control unit per increasing percent of performance. 


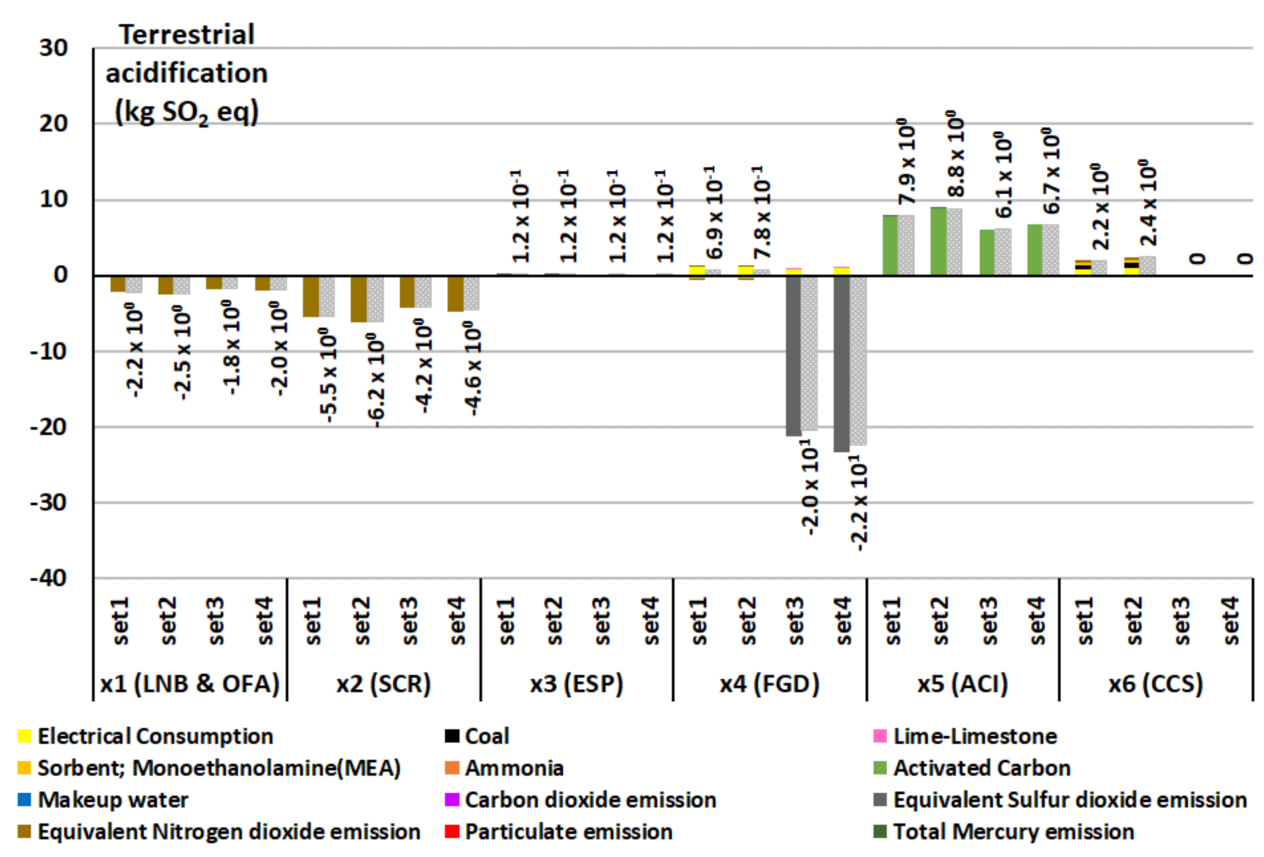

Figure 5. ADP impact of each pollution control unit per increasing percent of performance.

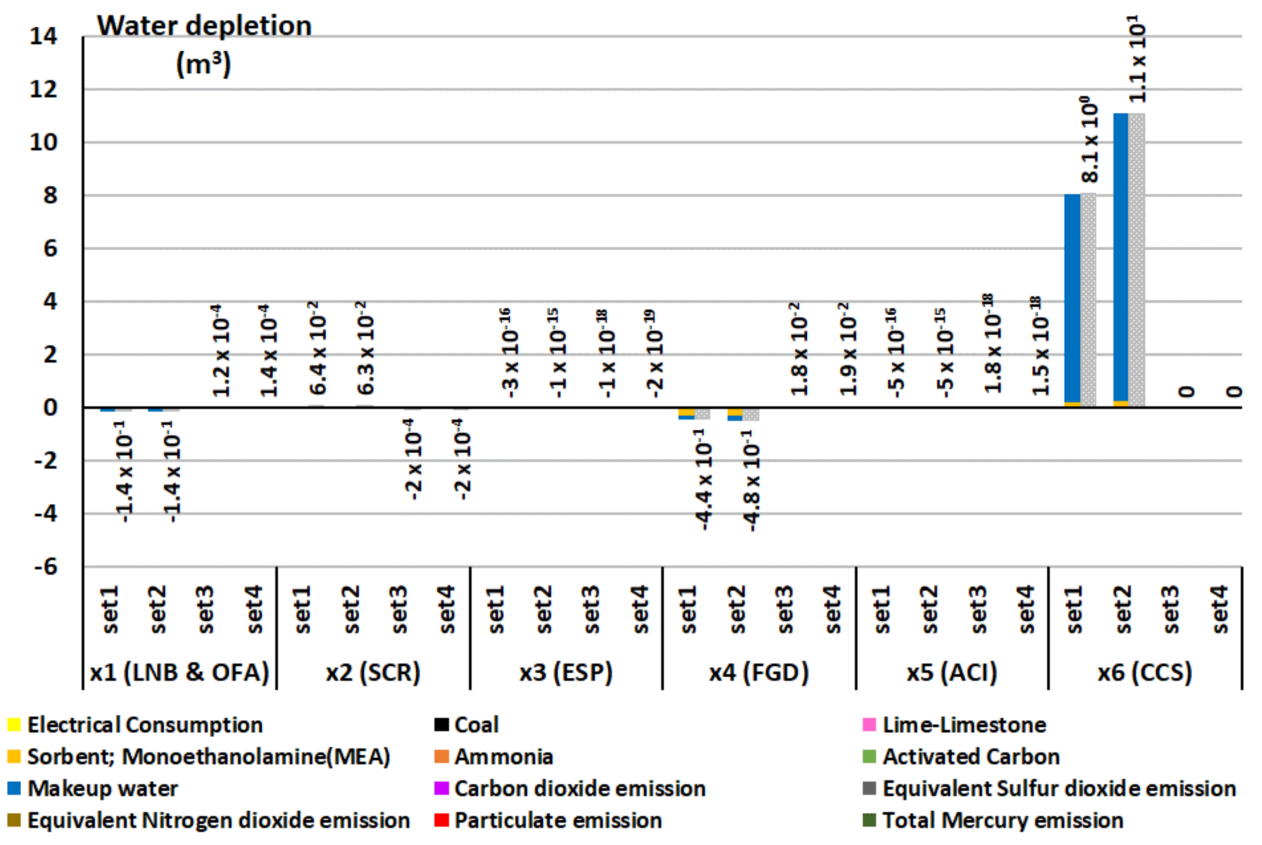

Figure 6. WD impact of each pollution control unit per increasing percent of performance.

\subsection{Global Warming Potential (GWP)}

From the results, it is very clear that enhancement of the carbon dioxide capture unit results in a net decrease of the global warming impact. With the amine system of the $\mathrm{CO}_{2}$ capture unit for both the ultra-super critical and super critical scenario, more than five tons of $\mathrm{CO}_{2}$ emission was reduced per one percent of removal efficiency increasing. Scenarios 3 and 4 are not represented in Figure 2, since those cases did not have a carbon dioxide capture unit. The results of this research also reveal that efforts to reduce the environmental global warming impact through the use of amine systems can create others indirect environmental impacts. This is largely due to the high energy penalty from the equivalent electricity consumed in the solvent regeneration reboiler column. Powerplants require greater coal consumption to compensate for the energy used in this process; thus, the global warming effect from acquiring and burning the larger amount of coal required 
releases more GHGs into the atmosphere. Another indirect source of the global warming impact of carbon dioxide capture units is the amount of amine solution added into the system, which increases as the load of carbon dioxide increases. Although the effects of this amine solution are relatively low compared to electricity and coal, they can be avoided. The aforementioned indirect impact is about $25 \%$ of the amount that can be directly captured by a carbon capture unit. For the global warming impact from the mercury capture process by activated carbon, it was found that increased activated carbon consumption resulted in a significant, indirect global warming impact, while the effect of energy usage is not singificant. Meanwhile, the energy used to enhance the efficiency of $\mathrm{SO}_{2}$ removal by the FGD unit is also a global warming impact source. Nonetheless, increasing the efficiency of the FGD unit also contributes to reduce trivial global warming impacts, since reduced levels of sulfur dioxide in the exhaust gas entering the carbon dioxide capture system reduces the use of the amine solution usage, and subsequently, indirectly diminishes the global warming impact. It is clear that increasing the efficiency of the remaining units has almost no effect on global warming.

\subsection{Human Toxicity (HT)}

Mercury had the most significant role in affecting human toxicity. Increasing the efficiency of the mercury capture of ACI unit could reduce the impact of 400-500 kg per percentage increase in efficiency. However, obtaining the activated carbon used in this process also brought an additional human toxicity impact, about $1 / 3$ of the total impact. The aforementioned results are consistent with many studies which indicated that the production of activated carbon potentially impacts the environment, especially in terms of human toxicity [64-66]. Increasing the carbon capture performance also affects the human toxicity impact due to the increased amount of coal required and the surplus electric power usage. There is no obvious side effect of human toxicity impact when increasing the performance of the other remaining units.

\subsection{Particulate Matter (PM)}

Increasing particulate matter control efficiency in the ESP unit does not create an additional PM impact, while increasing the efficiency of mercury removal directly results in increasing this impact. Since $\mathrm{NO}_{\mathrm{x}}$ is a component that causes the PM impact, increasing the efficiency of $\mathrm{NO}_{\mathrm{x}}$ removal deducts the environmental impact on the PM impact as well. Since $\mathrm{NO}_{\mathrm{x}}$ is a component that causes the PM impact, increasing the efficiency of $\mathrm{NO}_{\mathrm{x}}$ removal reduces the environmental impact on $\mathrm{PM}$ impact as well. Additionally, the same behavior occurs with the case of FGD units, since $\mathrm{SO}_{2}$ is also cause of PM impact.

\subsection{Acidification Potential (ADP)}

Both $\mathrm{SO}_{2}$ and $\mathrm{NO}_{\mathrm{x}}$ in flue gas have potential acidification impacts on the environment. Therefore, increasing the efficiency of those gas removal units-LNB \& OFA, SCR, and FGD - directly affects the acidification impact. Yet, based on the fact that the acidification impact per unit mass of gas $\mathrm{SO}_{2}$ is greater than gas $\mathrm{NO}_{x}$, efforts to reduce $\mathrm{SO}_{2}$ have more noticeable effects than reducing $\mathrm{NO}_{\mathrm{x}}$ for this impact aspect. The capture of mercury and carbon dioxide indirectly affects the acidity in the atmosphere through the process of obtaining and utilizing activated carbon, coal, and electricity.

\subsection{Water Depletion (WD)}

Among the pollution control units, CCS units had the most direct water consumption unit, therefore increasing the efficiency of the CCS units directly affects the WD problem. Yet, it can be seen that small amounts of water depletion reduced when increasing the performance in the LNB \& OFA, SCR, and FGD units. Enhancing the capacity of those units also meant removing the burden of energy requirement, as $\mathrm{SO}_{2}$ and $\mathrm{NO}_{x}$ can be absorbed by the MEA solvent. 


\subsection{End-Point Impact Analysis (Pt)}

To compare how increasing the performance of various pollution control units affects the overall environmental aspects simultaneously, end-point analysis using the ReCiPe method was applied to the mid-point result. Since it can be seen that the thermal efficiency of the ultra-supercritical powerplants is better than the supercritical powerplants, only the results for the ultra-supercritical powerplants with a carbon capture unit are shown in Figure 7. After normalization and weighing, all the mid-point impact unit dimensions were converted into identical unit-Point (Pt)—so that they could be combined. It is evident that increasing the efficiency of pollution control units, in addition to directly reducing the environmental impact of their primary functions, also affects other indirect environmental impacts. The overall environmental impact (black bars in Figure 7) is an indicator of whether pollution control units are environmentally friendly, from the perspective of the considered environmental aspects. For the LNB \& OFA and SCR units, in addition to directly reducing the environmental impact of terrestrial acidification, the units can also reduce particulate matter. Moreover, increasing their efficiency has less impact on other environmental aspects, making their overall environmental impact low. In the case of the ESP unit, its direct function (PM capture) is the only thing that reduced its environmental impact. Similar to the LNB \& OFA and SCR units, the operation of the ESP unit did not cause any other consequential environmental impacts. The main function of the FDG unit is to reduce the human toxicity impact, yet it is inevitable that it can cause other effects, including a global warming potential and acidification potential due to its higher energy requirement. This result is the reverse of the carbon capture unit, which has a key function of reducing global warming, but in turn, human toxicity, acidification, and particulate matter effects are unavoidable. A similar outcome of both units is that they produce higher overall environmental impacts. For mercury capture units, increasing its efficiency directly reduces the human toxicity impact and other indirect disadvantages from activated carbon acquisition and particulate matter, which account for around $20 \%$. However, there are no results for the pollution control units which indicate a water depletion impact, since the normalization value of water depletion using the ReCiPe method is zero.

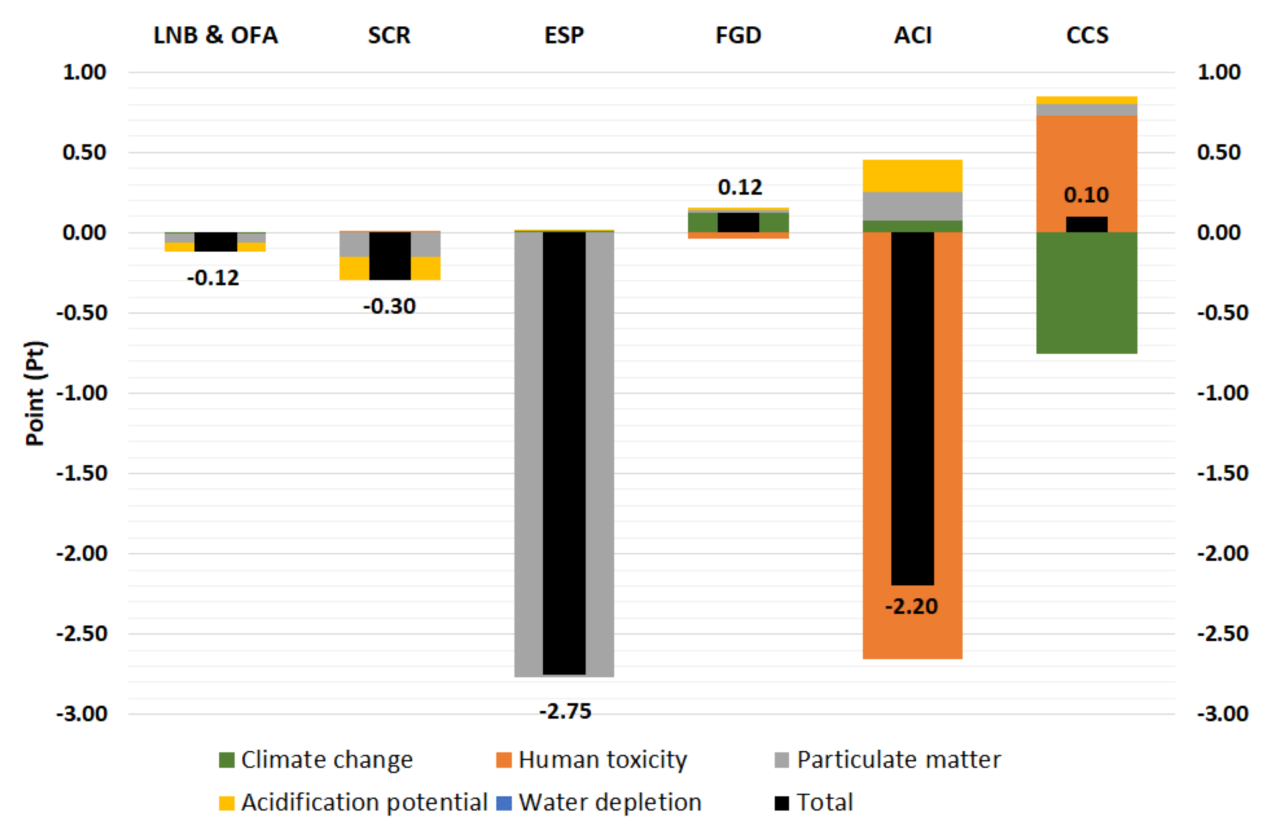

Figure 7. End-point analysis of each pollution control unit.

\subsection{Economic Analysis}

From the results mentioned above, control units in which the problem shifting clearly occurred were FGD and CCS. While FGD and other remaining control units are still requirement due to the emission control law and regulation, it is not for the CCS unit. The 
economic point of view is another aspect that stakeholders should know before deciding whether the CCS unit is still required. Table 12 is the annual cost comparison of ultrasupercritical with and without carbon capture unit. It can be concluded from the data that the total annual cost of a plant with a CCS unit is more expansive than a plant without CCS, almost $90 \%$. This difference could be smaller if a carbon tax is considered. Additional expenses are not only directly from CCS, but is also from additional burden on other control units. It can be seen that about $20-30 \%$ of the costs increase in the ESP and FGD units. This increased expenditure can be divided into three categories: fixed O\&M, variable O\&M, and annualized capital. Among these, annualized capital is major while fixed $O \& M$ is minor. It can imply that other impacts from the construction phase and acquisition of construction materials, excluded from this study, are also significant potential to be consider. This results also show that the boundary of problem shifting is not only limited to the environmental aspect, but also to other aspects, i.e., the economic aspect.

Table 12. Comparison of the overall ultra-supercritical plant cost with and without a CCS unit.

\begin{tabular}{|c|c|c|c|c|c|c|c|c|}
\hline \multirow{3}{*}{ Unit } & \multicolumn{2}{|c|}{ Fixed O\&M * } & \multicolumn{2}{|c|}{ Variable O\&M } & \multicolumn{2}{|c|}{ Annulized Capital } & \multicolumn{2}{|c|}{ Total Annual Cost } \\
\hline & \multicolumn{8}{|c|}{$\mathrm{M} \$ / \mathrm{yr}^{* *}$} \\
\hline & $w$ & $w / o$ & $w$ & $w / o$ & $w$ & $w / o$ & $w$ & $w / o$ \\
\hline LNB \& OFA & 0.139 & 0.139 & 0 & 0 & 1.048 & 1.048 & 1.187 & 1.187 \\
\hline SCR & 0.848 & 0.751 & 2.386 & 1.602 & 3.714 & 3.097 & 6.948 & 5.45 \\
\hline $\mathrm{ACI}$ & 0.086 & 0.086 & 0.034 & 0.021 & 0.009 & 0.011 & 0.129 & 0.118 \\
\hline ESP & 1.039 & 0.962 & 3.508 & 2.511 & 5.726 & 4.590 & 10.27 & 8.063 \\
\hline FGD & 11.24 & 9.812 & 14.35 & 7.358 & 20.11 & 16.71 & 45.70 & 33.88 \\
\hline CCS & 18.98 & 0 & 98.11 & 0 & 80.30 & 0 & 187.4 & 0 \\
\hline Base Plant & 26.68 & 23.93 & 45.31 & 64.68 & 117.3 & 101.4 & 189.3 & 190 \\
\hline Land & 0 & 0 & 0 & 0 & 0.114 & 0.114 & 0.114 & 0.114 \\
\hline Total & 59.01 & 35.68 & 163.7 & 76.17 & 228.3 & 126.9 & 451 & 238.8 \\
\hline
\end{tabular}

\section{Conclusions}

Pollution prevention units are necessary for coal-fired powerplants. Each unit has a primary function to reduce one environmental aspect. Increasing the efficiency of those pollution control units can reduce the environmental impact further, yet there is a tradeoff since increasing that performance has greater other environmental impacts that should be considered. Increasing the performance of the CCS and FGD units resulted in higher overall environmental impacts due to their energy penalties. The ACI unit can reduce the human toxicity effects, but it also increases the particulate matter and has greater impacts from activated carbon production. Therefore, it can be seen that the environmental assessment using the LCA method provides a comprehensive overview of the impact, which is better than considering only the direct impacts. If this methodology is applied to other processes rather than a coal-fired power plant with pollution control units, it will provide additional information about the indirect environmental impacts. This will provide policymakers with the opportunity to establish sustainable directions for environmental problem solving at the macro-economic scale.

Author Contributions: H.P. and P.U. substantially contributed in conceptualization, methodology, formal analysis, original draft preparation, and supervision. All authors have read and agreed to the published version of the manuscript.

Funding: This research was supported by Thammasat School of Engineering, Thammasat University. Institutional Review Board Statement: Not applicable.

Informed Consent Statement: Not applicable. 
Data Availability Statement: The datasets generated during and analysed during the current study are not publicly available due to restrictions of publishing the database from Licensed Software, but are available from the corresponding author on reasonable request.

Acknowledgments: The authors gratefully acknowledge the financial support provided by Thammasat School of Engineering, Thammasat University.

Conflicts of Interest: The authors declare no conflict of interest.

\section{References}

1. Enerdata. Global Energy Statistical Yearbook. 2017. Available online: https://yearbook.enerdata.net/electricity/electricitydomestic-consumption-data.html (accessed on 31 January 2018).

2. Li, M.; Zhang, D.; Li, C.-T.; Selin, N.E.; Karplus, V.J. Co-benefits of China's climate policy for air quality and human health in China and transboundary regions in 2030. Environ. Res. Lett. 2019, 14, 084006. [CrossRef]

3. Muller, N.Z.; Mendelsohn, R.; Nordhaus, W.D. Environmental Accounting for Pollution in the United States Economy. Am. Econ. Rev. 2011, 101, 1649-1675. [CrossRef]

4. Jakob, M.; Steckel, J.C.; Jotzo, F.; Sovacool, B.K.; Cornelsen, L.; Chandra, R.; Edenhofer, O.; Holden, C.; Löschel, A.; Nace, T.; et al. The future of coal in a carbon-constrained climate. Nat. Clim. Chang. 2020, 10, 704-707. [CrossRef]

5. Andrae, A.; Ab, S.K. Comparative screening life cycle impact assessment of renewable and fossil power supply for a radio base station site. Int. J. Green Technol. 2015, 1, 21-34. [CrossRef]

6. Cristóbal, J.; Guillén-Gosálbez, G.; Jiménez, L.; Irabien, A. Optimization of global and local pollution control in electricity production from coal burning. Appl. Energy 2012, 92, 369-378. [CrossRef]

7. Rigotto, R.M. The inclusion of health in environmental impact studies: Case report of a coal-fired power plant in Ceará State. Ciên. Saúde Colet. 2009, 14, 2049-2059. [CrossRef] [PubMed]

8. Song, Q.; Li, J. Greenhouse gas emissions from the usage of typical e-products by households: A case study of China. Clim. Chang. 2015, 132, 615-629. [CrossRef]

9. Zhou, J.S.; Luo, Z.Y.; Zhu, Y.Q.; Fang, M.X. Mercury Emission and its Controlling Pollutants in Coal-Fired Power Plants in China. In Advanced Topics in Science and Technology in China; Springer: Berlin, Germany, 2013.

10. Shahzad, B.K.; Yousaf, M. Coal Fired Power Plants: Emission Problems and Controlling Techniques. J. Earth Sci. Clim. Chang. 2017, 8, 404. [CrossRef]

11. Grahame, T.J.; Schlesinger, R.B. Health Effects of Airborne Particulate Matter: Do We Know Enough to Consider Regulating Specific Particle Types or Sources? Inhal. Toxicol. 2007, 19, 457-481. [CrossRef] [PubMed]

12. Information Collection Request. Available online: http://www.epa.gov/ttn/atw/utility/utilitypg.html (accessed on 13 March 2019).

13. Ribeiro, J.; Taffarel, S.R.; Sampaio, C.H.; Flores, D.; Silva, L.F. Mineral speciation and fate of some hazardous contaminants in coal waste pile from anthracite mining in Portugal. Int. J. Coal Geol. 2013, 109-110, 15-23. [CrossRef]

14. Tian, H.Z.; Lu, L.; Hao, J.M.; Gao, J.J.; Cheng, K.; Liu, K.Y.; Qiu, P.P.; Zhu, C.Y. A Review of Key Hazardous Trace Elements in Chinese Coals: Abundance, Occurrence, Behavior during Coal Combustion and Their Environmental Impacts. Energy Fuels 2013, 27, 601-614. [CrossRef]

15. GAINS. Greenhouse Gas and Air Pollution Interactions and Synergies - South Asia Program; International Institute of Applied Systems Analysis: Laxenburg, Austria, 2012; Available online: https:/ /iiasa.ac.at/web/home/research/researchPrograms/air/Asia.html (accessed on 27 April 2019).

16. Feeley, T.J.; Skone, T.J.; Stiegel, G.J.; McNemar, A.; Nemeth, M.; Schimmoller, B.; Murphy, J.T.; Manfredo, L. Water: A critical resource in the thermoelectric power industry. Energy 2008, 33, 1-11. [CrossRef]

17. Wang, Z.; Cen, K.; Zhou, J.; Fan, J. Application and Economic Analysis of the Multi-Pollutants Removal Technology Incor-porated with Ozone Oxidization and Alkali Solution Adsorption. In Simultaneous Multi-Pollutants Removal in Flue Gas by Ozone; Springer: Berlin/Heidelberg, Germany, 2014; pp. 95-106.

18. Wu, X.; Wu, K.; Zhang, Y.; Hong, Q.; Zheng, C.; Gao, X.; Cen, K. Comparative life cycle assessment and economic analysis of typical flue-gas cleaning processes of coal-fired power plants in China. J. Clean. Prod. 2017, 142, 3236-3242. [CrossRef]

19. Córdoba, P. Status of Flue Gas Desulphurisation (FGD) systems from coal-fired power plants: Overview of the physic-chemical control processes of wet limestone FGDs. Fuel 2015, 144, 274-286. [CrossRef]

20. Franco, A.; Diaz, A.R. The future challenges for "clean coal technologies": Joining efficiency increase and pollutant emission control. Energy 2009, 34, 348-354. [CrossRef]

21. Han, J.; Wang, L.; Li, J. Selection and application of technology of high efficient removal for flue gas of coal-fired power plant. J. Environ. Sci. Manag. 2011, 36, 86-89. Available online: http:// search.cnki.net/down/default.aspx?filename=BFHJ201101024 $\&$ dbcode=CJFD\&year=2011\&dflag=pdfdown (accessed on 2 September 2019).

22. Pui, D.Y.; Chen, S.-C.; Zuo, Z. PM2.5 in China: Measurements, sources, visibility and health effects, and mitigation. Particuology 2014, 13, 1-26. [CrossRef]

23. Mao, X.; Zeng, A.; Hu, T.; Xing, Y.; Zhou, J.; Liu, Z. Co-control of local air pollutants and $\mathrm{CO}_{2}$ from the Chinese coal-fired power industry. J. Clean. Prod. 2014, 67, 220-227. [CrossRef] 
24. Ma, S.; Chai, J.; Jiao, K.; Ma, L.; Zhu, S.; Wu, K. Environmental influence and countermeasures for high humidity flue gas discharging from power plants. Renew. Sustain. Energy Rev. 2017, 73, 225-235. [CrossRef]

25. Xiong, Y.; Niu, Y.; Wang, X.; Tan, H. Pilot Study on In-depth Water Saving and Heat Recovery from Tail Flue Gas in Lignite-fired Power Plant. Energy Procedia 2014, 61, 2558-2561. [CrossRef]

26. $\mathrm{Wu}, \mathrm{J}$. The development and application of SCR denitrification technology in power plant. In IOP Conference Series: Earth and Environmental Science; IOP Publishing: Bristol, UK, 2017; Volume 100, p. 12033.

27. Moretti, A.L.; Jones, C.S. Advanced Emissions Control Technologies for Coal-Fired Power Plants. Presented at Power-Gen Asia, Bangkok, Thailand. 2012. Available online: https://andymaypetrophysicist.files.wordpress.com/2017/01/advanced_emissions_ control_coal_br-1886.pdf (accessed on 30 June 2019).

28. Fang, J.; Jin, X.; Huang, K. Life cycle analysis of a combined $\mathrm{CO}_{2}$ capture and conversion membrane reactor. J. Membr. Sci. 2018, 549, 142-150. [CrossRef]

29. Thitakamol, B.; Veawab, A.; Aroonwilas, A. Environmental impacts of absorption-based $\mathrm{CO}_{2}$ capture unit for post-combustion treatment of flue gas from coal-fired power plant. Int. J. Greenh. Gas. Control. 2007, 1, 318-342. [CrossRef]

30. Mores, P.; Scenna, N.; Mussati, S. Post-combustion $\mathrm{CO}_{2}$ capture process: Equilibrium stage mathematical model of the chemical absorption of $\mathrm{CO}_{2}$ into monoethanolamine (MEA) aqueous solution. Chem. Eng. Res. Des. 2011, 89, 1587-1599. [CrossRef]

31. Rodríguez, N.; Mussati, S.; Scenna, N.J. Optimization of post-combustion $\mathrm{CO}_{2}$ process using DEA-MDEA mixtures. Chem. Eng. Res. Des. 2011, 89, 1763-1773. [CrossRef]

32. Zhao, B.; Yi, H.; Tang, X.; Li, Q.; Liu, D.; Gao, F. Copper modified activated coke for mercury removal from coal-fired flue gas. Chem. Eng. J. 2016, 286, 585-593. [CrossRef]

33. Du, W.; Yin, L.; Zhuo, Y.; Xu, Q.; Zhang, L.; Chen, C. Performance of CuOx-neutral $\mathrm{Al}_{2} \mathrm{O}_{3}$ sorbents on mercury removal from simulated coal combustion flue gas. Fuel Process. Technol. 2015, 131, 403-408. [CrossRef]

34. Liu, Y.X.; Zhang, J.; Sheng, C.D.; Zhang, Y.C.; Yuan, S.J. New research progress in sorbents for removal of mercury in coal-fired flue gas. Mod. Chem. Ind. 2008, 11, 19-25. Available online: https://pay.cnki.net/zscsdoc/download?flag=cnkispace\&plat= cnkispace \&filename=XDHG200811003\&dbtype=CJFD\&year=2008\&dtype=pdf (accessed on 5 June 2019).

35. Zheng, Y.; Jensen, A.D.; Windelin, C.; Jensen, F. Dynamic measurement of mercury adsorption and oxidation on activated carbon in simulated cement kiln flue gas. Fuel 2012, 93, 649-657. [CrossRef]

36. Tan, Z.Q.; Sun, L.S.; Xiang, J.; Zeng, H.C.; Liu, Z.H.; Hu, S.; Qiu, J.R. Gas-phase elemental mercury removal by novel carbon-based sorbents. Carbon 2012, 50, 362-371. [CrossRef]

37. Kim, R.E. Global governance: Problem shifting in the Anthropocene and the limits of international law. In Research Handbook on International Law and Natural Resources; Morgera, E., Kulovesi, K., Eds.; Edward Elgar Publishing: Cheltenham, UK, 2016.

38. Yang, Y.; Bae, J.; Kim, J.; Suh, S. Replacing Gasoline with Corn Ethanol Results in Significant Environmental Problem-Shifting. Environ. Sci. Technol. 2012, 46, 3671-3678. [CrossRef] [PubMed]

39. Capaz, R.S.; de Medeiros, E.M.; Falco, D.G.; Seabra, J.E.; Osseweijer, P.; Posada, J.A. Environmental trade-offs of renewable jet fuels in Brazil: Beyond the carbon footprint. Sci. Total. Environ. 2020, 714, 136696. [CrossRef]

40. Williamson, P.; Wallace, D.W.; Law, C.S.; Boyd, P.W.; Collos, Y.; Croot, P.; Denman, K.; Riebesell, U.; Takeda, S.; Vivian, C. Ocean fertilization for geoengineering: A review of effectiveness, environmental impacts and emerging governance. Process. Saf. Environ. Prot. 2012, 90, 475-488. [CrossRef]

41. Jones, N. Safeguarding Against Environmental Injustice: $1.5^{\circ} \mathrm{C}$ Scenarios, Negative Emissions, and Unintended Consequences. Carbon Clim. Law Rev. 2018, 12, 23-30. [CrossRef]

42. Xue, B.; Mitchell, B.; Geng, Y.; Ren, W.; Müller, K.; Ma, Z.; de Oliveira, J.A.P.; Fujita, T.; Tobias, M. A review on China's pollutant emissions reduction assessment. Ecol. Indic. 2014, 38, 272-278. [CrossRef]

43. Pehnt, M.; Henkel, J. Life cycle assessment of carbon dioxide capture and storage from lignite power plants. Int. J. Greenh. Gas. Control. 2009, 3, 49-66. [CrossRef]

44. Sebastián, F.; Royo, J.; Gómez, M. Cofiring versus biomass-fired power plants: GHG (Greenhouse Gases) emissions savings comparison by means of LCA (Life Cycle Assessment) methodology. Energy 2011, 36, 2029-2037. [CrossRef]

45. Oró, E.; Gil, A.; de Gracia, A.; Boer, D.; Cabeza, L.F. Comparative life cycle assessment of thermal energy storage systems for solar power plants. Renew. Energy 2012, 44, 166-173. [CrossRef]

46. Hondo, H. Life cycle GHG emission analysis of power generation systems: Japanese case. Energy 2005, 30, 2042-2056. [CrossRef]

47. Odeh, N.A.; Cockerill, T.T. Life cycle GHG assessment of fossil fuel power plants with carbon capture and storage. Energy Policy 2008, 36, 367-380. [CrossRef]

48. Schakel, W.; Meerman, H.; Talaei, A.; Ramírez, A.; Faaij, A. Comparative life cycle assessment of biomass co-firing plants with carbon capture and storage. Appl. Energy 2014, 131, 441-467. [CrossRef]

49. Viebahn, P.; Vallentin, D.; Höller, S. Prospects of carbon capture and storage (CCS) in India's power sector-An integrated assessment. Appl. Energy 2014, 117, 62-75. [CrossRef]

50. Van Caneghem, J.; De Greef, J.; Block, C.; Vandecasteele, C. NOx reduction in waste incinerators by selective catalytic reduction (SCR) instead of selective non catalytic reduction (SNCR) compared from a life cycle perspective: A case study. J. Clean. Prod. 2016, 112, 4452-4460. [CrossRef]

51. Feng, C.; Gao, X.; Tang, Y.; Zhang, Y. Comparative life cycle environmental assessment of flue gas desulphurization technologies in China. J. Clean. Prod. 2014, 68, 81-92. [CrossRef] 
52. Mantripragada, H.C.; Zhai, H.; Rubin, E.S. Boundary Dam or Petra Nova-Which is a better model for CCS energy supply? Int. J. Greenh. Gas. Control. 2019, 82, 59-68. [CrossRef]

53. Zhai, H.; Rubin, E.S. Systems Analysis of Physical Absorption of $\mathrm{CO}_{2}$ in Ionic Liquids for Pre-Combustion Carbon Capture. Environ. Sci. Technol. 2018, 52, 4996-5004. [CrossRef] [PubMed]

54. Zhai, H.; Rubin, E.S. A Techno-Economic Assessment of Hybrid Cooling Systems for Coal- and Natural-Gas-Fired Power Plants with and without Carbon Capture and Storage. Environ. Sci. Technol. 2016, 50, 4127-4134. [CrossRef] [PubMed]

55. Zhai, H.; Ou, Y.; Rubin, E.S. Opportunities for Decarbonizing Existing U.S. Coal-Fired Power Plants via $\mathrm{CO}_{2} \mathrm{Capture}_{\text {, Utilization }}$ and Storage. Environ. Sci. Technol. 2015, 49, 7571-7579. [CrossRef] [PubMed]

56. Bell, R.D.; Buckingham, F.P. An overview of technologies for reduction of oxides of nitrogen from combustion furnaces. Alexandria: MPR Assoc 8 (2010): 2016. Available online: http:/ / www.mrp.com/uploads/news/nox-reduction-coal-fired.pdf (accessed on 4 March 2019).

57. Sorrels, J.L.; Randall, D.D.; Schaffner, K.S.; Fry, C.R. Selective Catalytic Reduction. In EPA Air Pollution Control Cost Manual; 2019. Available online: https:/ / www3.epa.gov/ttn/ecas/docs/SCRCostManualchapter7thEdition_2016.pdf (accessed on 4 August 2019).

58. United States Environmental Protection Agency, US.EPA. CAM Protocol for an ESP controlling PM from a Coal-Fired Boiler. 2016. Available online: https:/ / www3.epa.gov/ttnemc01/cam/espcam.pdf (accessed on 4 March 2019).

59. Air, P. Advanced Technologies for the Control of Sulfur Dioxide Emissions from Coal-Fired Boilers. 1999. Available online: https:/ / pdfs.semanticscholar.org/4196/36dada5f3d2a235b99b834ebefb5a2f01d4a.pdf (accessed on 4 March 2019).

60. Tan, L.; Shariff, A.; Lau, K.; Bustam, M. Factors affecting $\mathrm{CO}_{2}$ absorption efficiency in packed column: A review. J. Ind. Eng. Chem. 2012, 18, 1874-1883. [CrossRef]

61. Rezaei, F.; Rownaghi, A.A.; Monjezi, S.; Lively, R.P.; Jones, C.W. SOx/NOx Removal from Flue Gas Streams by Solid Adsorbents: A Review of Current Challenges and Future Directions. Energy Fuels 2015, 29, 5467-5486. [CrossRef]

62. Bamdad, H.; Hawboldt, K.; MacQuarrie, S. A review on common adsorbents for acid gases removal: Focus on biochar. Renew. Sustain. Energy Rev. 2018, 81, 1705-1720. [CrossRef]

63. Valverde, J.; Sanchez-Jimenez, P.; Perez-Maqueda, L. Ca-looping for postcombustion $\mathrm{CO}_{2}$ capture: A comparative analysis on the performances of dolomite and limestone. Appl. Energy 2015, 138, 202-215. [CrossRef]

64. Alade, A.O.; Amuda, O.S.; Bello, M.O. Life Cycle Inventory Analysis (LCIA) of production of activated carbons from selected agricultural materials. Pollution 2012, 44, 7275-7279. Available online: https:/ / www.researchgate.net/publication/272973462 Life_Cycle_Inventory_Analysis_LCIA_of_production_of_activated_carbons_from_selected_agricultural_materials (accessed on 5 July 2019).

65. Hjaila, K.; Baccar, R.; Sarrà, M.; Gasol, C.; Blánquez, P. Environmental impact associated with activated carbon preparation from olive-waste cake via life cycle assessment. J. Environ. Manag. 2013, 130, 242-247. [CrossRef] [PubMed]

66. Yahya, M.A.; Al-Qodah, Z.; Ngah, C.Z. Agricultural bio-waste materials as potential sustainable precursors used for activated carbon production: A review. Renew. Sustain. Energy Rev. 2015, 46, 218-235. [CrossRef] 